Vol. 10, n² | 2006

Varia

\title{
Protestant attitudes to violence: the early Dutch Republic
}

\section{Pieter Spierenburg}

\section{(2) OpenEdition \\ 1 Journals}

Electronic version

URL: https://journals.openedition.org/chs/215

DOI: $10.4000 /$ chs. 215

ISSN: 1663-4837

Publisher

Librairie Droz

Printed version

Date of publication: 1 December 2006

Number of pages: 5-31

ISBN: 978-2-600-01129-7

ISSN: 1422-0857

\section{Electronic reference}

Pieter Spierenburg, "Protestant attitudes to violence: the early Dutch Republic", Crime, Histoire \& Sociétés / Crime, History \& Societies [Online], Vol. 10, n² | 2006, Online since 01 January 2010, connection on 23 March 2022. URL: http://journals.openedition.org/chs/215 ; DOI: https://doi.org/ $10.4000 /$ chs. 215

This text was automatically generated on 23 March 2022.

(c) Droz 


\title{
Protestant attitudes to violence: the early Dutch Republic
}

\author{
Pieter Spierenburg
}

\section{AUTHOR'S NOTE}

I am grateful to Willem Frijhoff, Steve Hughes and Hans de Waardt for their comments on the draft version of this article. Earlier versions were delivered as a lecture at my department (Jan. 2004) and as a paper at the ESSHC, Berlin, March 2004; my thanks to those present for their remarks.

1 The word «violence» in the title of this article should be read as shorthand for interpersonal (physical) violence outside wars and episodes of collective protest ${ }^{3}$. For a journal devoted to crime and justice, the subject of Christian attitudes to fighting, quarrelling and killing needs no elaborate justification. From a broader historiographical perspective, this subject forms part of the wider research field of religious influences on personal conduct. We know a good deal about the efforts of Protestant as well as Catholic clergy and moralists, especially during and just after the Reformation and the Counter-Reformation, to transform the behavior and attitudes of their flocks. However, most of the studies in question focus on marriage and sexuality, devotional practices, or ritual and festivals, against the background of broader transformations such as confessionalization or the reform of popular culture ${ }^{4}$. Yet, the criminalization of violent behavior is one more example of such broader transformations during the sixteenth and seventeenth centuries and the question whether religious propaganda contributed to it seems pertinent.

2 As far as can be ascertained (in languages accessible to this author), there are only a few exceptions to the scarcity of studies dealing with religious attitudes toward interpersonal violence in early modern Europe. The historical literature on the duel, for example, usually mentions its condemnation by Catholic and Protestant authors, as well as their rejection of the honor code which underlay dueling ${ }^{5}$. Studies of 
consistorial discipline, in particular by Herman Roodenburg, note that fights, some of them with knives, were among the undesirable activities for which church members could be censured ${ }^{6}$. A few English studies are located on the margin of our subject. Peter Lake analyzes pamphlets written at the occasion of murderers' executions and inquires into their Protestant, especially Puritan content ${ }^{7}$. Malcolm Gaskill investigates how changing conceptions of divine providence influenced the practice of and attitudes to fact-finding in homicide trials ${ }^{8}$. But the central question about religious views of tavern brawls, knife fighting, killing for honor, and similar activities remains largely unexplored ${ }^{9}$. This article is meant as a modest beginning with remedying that situation, as far as the Netherlands from the late sixteenth century to the late seventeenth are concerned.

3 The Dutch experience is particularly intriguing, because even a cursory look at the evidence suffices to conclude that we are facing a paradox: The Republic's Calvinists, although very keen on mediation between and consensus among their members, exhibited a very negative attitude to the formal reconciliation (zoen) after a homicide. More generally, they frowned upon all legal or semi-legal practices which might lead to an outcome other than an official criminal trial for any suspected killer. The attitudes of the Calvinists, who constituted the public Church (but no State $\operatorname{Church}^{10}$ ), quite probably contributed to the establishment of full prosecution for homicide. The shift from reconciliation to criminal prosecution was a long, drawn-out process in Holland, starting at least as early as the mid-fifteenth century, while its completion has not yet been fully documented (see below). In any case, the zoen survived for a long time as a precondition for obtaining remission.

The Calvinist preference for the criminal prosecution of homicide contrasts with the Church's positive attitude to reconciliation in most other types of conflict. This attitude clearly emerges from Manon van der Heijden's study of consistorial discipline (and criminal prosecution) in matters related to marriage and sexuality ${ }^{11}$. Although, for example, a spouse could obtain a divorce and remarry after the other partner had committed adultery, the consistory and the elders would first try every expedient to reconcile the couple. This preference for talking it over was even more conspicuous when it concerned the choice of marriage partners. According to Protestant law, throughout Europe, parental consent was a necessary prerequisite for marriage and Lutheran parents, for example, regularly had their children's clandestine marriages annulled in court ${ }^{12}$. Nevertheless, consistories in Dutch towns actively mediated in conflicts between children and parents over the former's choice of partners, always aiming at a consensus about who married whom. For Europe as a whole, Heinz Schilling has posited a distinct separation between secular justice and ecclesiastical handling of undesirable behavior, whereby Calvinist consistorial discipline served as the model - or even ideal type - of the latter. According to Schilling, ecclesiastical discipline (Sündenzucht) meant reconciliation instead of punishment: reconciliation of the sinner with the church community and, according to contemporary views, also with God. Thereby the sinner was saved and the purity of the congregation maintained. By contrast, secular justice meant punishment and retaliation, with little concern for reconciliation with God and the community ${ }^{13}$. Why then did Dutch Calvinists opt for secular justice in cases of homicide?

5 This study is based on two sets of sources, one of which consists of the protocols of provincial and regional synods of the Reformed Church and some of the classes (units of 
several parishes) represented there in the late sixteenth and seventeenth centuries. These protocols have been published in indexed volumes, which make it easy to trace references to violence in them. There are three series of editions, two of them already old but well-indexed nevertheless. Reitsma and Van Veen (eight volumes, 1892-1899) published the records of provincial and regional synods throughout the Northern Netherlands between 1572 and 1620. Knuttel (six volumes, 1908-1916) did the same for the regional synods of Southern Holland in the subsequent period, 1621-1700. The first volume of the more recent series (dealing with the cases, questions and remarks that individual classes, in Holland and Brabant, brought to the synods' meetings, 1573-1620) appeared in 1980 and seven volumes, by various editors, have been published to date. Taken together, these series offer a rich overview of Reformed opinions about church doctrine and practically every aspect of daily life.

The second set of sources consists of moralistic tracts by Protestant authors, also mainly Calvinists. Although violence was not their primary or even secondary concern, a number of them touched on this subject, some very cursorily, others more elaborately. The way in which I assembled this set of moralistic works needs some explanation, if only to enable the reader to judge whether the outcome is likely or not to be biased. I collected the original set of titles a few decades ago, when my main interest was in manner books. In the systematic catalogues of the Amsterdam University Library and the Royal Library in The Hague, the titles of manner books were in the same card box then with works of a general moralistic nature. I wrote down the general moralistic titles as well and in the 1990s I consulted all these works, to see if they contained anything on violence. Works that had no reference whatsoever to violence were put aside. It would be foolish to maintain that the final set is in any way complete; several of the authors in question, for example, have published dozens of other books. But the way this final set was compiled, I believe, ensures that it is a more or less representative sample of Protestant, especially Calvinist, attitudes to violence in the Dutch Republic. Its relative uniformity, moreover, suggests that a more intensive investigation would yield little or no information with additional value. Even though the synod protocols are older on average, I will start with the relatively uniform message of these moralistic works ${ }^{14}$.

\section{The Moralists}

7 The books are discussed in chronological order, according to the year of the edition consulted. The sample character of my set makes it imperative to mention every author, even if only briefly. Some of the later authors, however, get little space simply because they repeat their predecessors. The relative uniformity of this literature makes it superfluous to compare the available editions of each separate work. In all cases but one, the edition consulted is the oldest extant in Dutch libraries.

8 As we will see, an occasional author was non-Reformed, or Reformed but not a minister. Many of them, on the other hand, count as representatives of the Nadere Reformatie the movement to promote, after the reformation of doctrine, a second reformation, aimed at good Christian conduct. At first sight, the label of Nadere Reformatie may seem redundant, since the authors earned it in the first place by writing the sort of books I am interested in. Upon second thought, this label is indicative, because it alerts us to the connection with English Protestantism and Puritanism in particular. At the 
(national) Synod of Dordt in 1619, the Dutch Reformed Church had definitively proclaimed its adherence to Calvin's doctrine of predestination. The Anglican delegates in Dordt had expressed their agreement, but the Anglican Church drifted away from its belief in predestination soon afterwards. The Puritans remained true to this doctrine, which earned them praise from Dutch Calvinists. In addition, the Nadere Reformatie shared the Puritans' predilection for a sober life-style. The Nadere Reformatoren eagerly read Puritan works and several of them translated one or more of these works into Dutch $^{15}$. It may very well be that their views of violence, too, were influenced by English Puritanism. In the absence of detailed studies on the issue, this supposition cannot be confirmed ${ }^{16}$.

The oldest work in the sample, Pieter Jansz Twisck's 1604 treatise on twist (which can be translated as quarrelling), happens to be one of the few by a non-Reformed author. Twisck (1565-1636) was a Mennonite minister in Hoorn ${ }^{17}$. This is also the only work devoted exclusively to a theme related to violence, but it contains few interesting details. Quarrelling is always bad and destructive, Twisck assures us, bolstering his case with numerous examples from the Bible and the literature of classical Antiquity. of course we would not have expected Mennonites, who advocated a principled defenselessness, to be less condemnatory than Calvinists about private violence. The only remark about events close to Twisck's own time concerns a supposed number of eighty thousand victims of the Duke of Alba's regime, plus no less than twenty million people that the Spaniards allegedly killed in the Americas ${ }^{18}$. The fact that he partook of the widespread anti-Spanish propaganda, suggests that he may not have been unhappy with the military campaigns of the Dutch army. In later years, many Mennonites would acquiesce in the idea of national defense against the country's enemies.

Military force against the enemy certainly was no problem for Willem Teellinck (1579-1629), Reformed minister in Middelburg. Dutch church historians have proclaimed Teellinck, who published his first book in 1608, as the father of the Nadere Reformatie. He was personally acquainted with many Puritans, whom he met, including his Puritan wife, during a stay in England ${ }^{19}$. Next to this influence, his views of the human body derived from Galenic humoral pathology, on which he based, among other things, the necessity of avoiding quarrels and aggression ${ }^{20}$. The 1622 book considered here was meant for Christian soldiers and the author dedicated it to the Princes Maurice and Frederic Henry. Of course Christian soldiers and officers should trust in God and act upon that trust. One passage bears on the subject of interpersonal violence. To appreciate it, we have to know that the book is a dialogue among four persons: a prince (Nehemia), a councilor (Hanania), a «teacher» (Esra) and a «worldly-wise person» (Semaia). Semaia is always prepared to compromise on the basis of his practical knowledge, but the prophet/ minister Esra constantly corrects him. This happens, for example, when the company discusses the sins of soldiers: primarily visiting prostitutes but also mutual fighting.

11 Esra: Soldiers consider themselves brave when, apart from combating the enemy, they do not tolerate any injury from each other. Hanania: For the sake of their idle reputation they often challenge each other, also with the sword; this causes a lot of blood to flow. Semaia: Do you want to turn soldiers into cowardly chickens, then, who let themselves be screwed by everyone? Hanania: No, but they must learn to use their physical strength against the enemy only. Esra adds: A good soldier conquers the devil. Semaia remains unconvinced: «But how do you want a brave soldier to react, when he 
is challenged by another one? Should he ignore it just like that and hide his tail under his ass like a scared dog and slink away?» Esra's reply: No, in a dignified manner he should say that he refuses to fight with the devil's servant, or anyone who acts as the slave of his own passions. Esra explains further: Even those who strongly care for their point d'honneur concede that a captain or a baron is not obliged to accept a challenge from an ordinary soldier. Similarly, a godly soldier does not have to lower himself into accepting a challenge to a duel from a roguish and unchristian fellow ${ }^{21}$.

Remarkably, this passage ends by explicitly mentioning the term «duel». In the historiography of dueling it is usually assumed that this custom still was exclusively aristocratic in the early seventeenth century and that it did not spread to common soldiers until later in that century. Perhaps that assumption reflects (French) trial practice rather than the duel's actual incidence. In any case, Teellinck blames common soldiers for dueling too. And he has some knowledge of the honor code involved, since he wants to convert its grading according to social rank into a religious grading. Teellinck has his alter ego, Esra, concluding the discussion about fights among military men with the remark that the country's well-being would be equally served if no manslaughters were pardoned, a suggestion which Nehemia promptly promises to follow.

The rejection of dueling returns in the next work, Everhardus Schuttenius' The Christian Warrior (1628). Schuttenius (1595-1655), Reformed minister in Zwolle, was a representative of the Nadere Reformatie, too; one of his accomplishments was the translation of a work by the Puritan writer Lewis Bayly. Nevertheless, Schuttenius' orthodoxy had been in doubt just after the Synod of Dordt, but a committee of two learned ministers had cleared him ${ }^{22}$. Dedicated to Frederic Henry, his Christian Warrior exposes the vices not only of military men but of three other social groups as well: ecclesiastics, political leaders, and ordinary (usually male) citizens. Anger is one of their possible vices, to which even some ecclesiastical persons succumb by showing too much zeal and fieriness in preaching and admonishing their flock.

With some satisfaction Schuttenius adds that one finds such fiery preachers mainly among Papists and Lutherans. In any case, anger is most apparent in military persons. They live according to the law of manliness and courage, which leads them to curse and quarrel often. «A soldier who does not want to seek revenge and retaliate immediately the harm and injustice done to him, by letting the burning fuse of his lust for revenge get to the gunpowder of his touchy and easily irritated heart, will thus be considered a coward and a failing sucker, as if the manliness and courage of a soldier's heart lay therein. $»^{23}$ Against this notion, Schuttenius argues that, first of all, soldiers have not been contracted to fight each other but only the common enemy. Moreover, their mutual violence has dangerous consequences, especially when it takes the form of a duel. Unfortunately, he adds, duels are very common nowadays and the devil is extremely pleased when he succeeds in inducing a duelist to kill his opponent.

In another chapter of his book, Schuttenius introduces a theme which later authors were to repeat; his reference to it is the oldest I have found so far. That is, everything which may lead to homicide, such as hate, envy, anger and lust for revenge, falls under the sixth commandment (Thou shallt not kill). He illustrates this argument with a simple parrallel: In a similar manner, dancing eventually leads to adultery and is therefore equally sinful ${ }^{24}$. 
16 Adamus Westermannus' Christian Navigation and Walkway (1631) contains pious admonitions for merchants, sailors and other travellers, to accompany them on their journeys ${ }^{25}$. One of his chapters deals with defense against the enemy. Apart from military attack, Westermannus explains, a traveller may be held up by pirates or straatschenders (street rogues). He allows the victims to defend themselves against such criminals, but only when four conditions apply: sudden, inescapable violence awaits the traveller; no other means of warding it off is available but to hit or even kill one's assailant; law enforcement agents are absent; one's own violence serves only for protection and not for revenge. These conditions are unsurprising, since they more or less conform to the criteria implicitly observed by the Amsterdam court for granting acquittal because of self-defense (in the homicide cases I studied from 1650 onward).

Petrus Baardt is an outsider in this series. His 1645 Track of Virtue, Portrayed in the Vices of the World has to be mentioned, because it entered my sample due to one passage which touches on attitudes to violence. The book is an adaptation of Johannes Flitnerus' Nebulo Nebulonum (Frankfurt 1620) and was published a year after its author's premature death. Baardt, a physician by training, wants to expose the vanities of the world, inspired by Erasmus' Praise of Folly. The author equates the military man with a jonker, for which the gentry of his native Frisia probably served as a model. Soldiers apparently associate their rifles with a willing maid:

A military man grins like a bear

As soon as he sees a naked gun

(But did I say «a naked girl»?

That was all too immodest) ${ }^{26}$

This comical tone returns throughout the book, but Baardt insists that he only portrays vices in order to promote virtue. His examples, Flitnerus and Erasmus, take us far away from the Puritan connection. Nevertheless, like the ministers before him, when contemplating violence Baardt primarily thinks of soldiers.

The book by Van Houten, revised by Voetius, not only takes us back to the Puritan connection, it is also the first aimed at the general reader instead of just soldiers or travellers. Its origins date from before 1637, but the oldest extant edition appeared in $1654^{27}$. Gisbertus Voetius (1589-1676), professor of theology in Utrecht, is a well-known figure in Dutch historiography, because he championed orthodox Calvinism within the Reformed Church and attacked Descartes ${ }^{28}$. The book under scrutiny here helps church members to ponder their sins, based on the ten commandments. Like Schuttenius, Voetius maintains that the sixth covers all hate, jealousy and conflict which potentially lead to violence. He also mentions the duel, warning that even when a man receives a formal challenge, he is not allowed to accept it. Like the prophet Esra in Teellinck's work, Voetius exhorts the secular authorities always to punish manslaughterers. He adds, however, that a court should never punish any criminal with excessive cruelty. Finally, he includes an intriguing new group of sinners not mentioned by his predecessors: «those people who entertain the opinion that one may arrest a thief but not a manslaughterer; rather they try to hide him [i.e. the manslaughterer] from the prosecuting officer $\aleph^{29}$. It is likely that Voetius, or Van Houten, knew from experience that many people thought that a man who had inadvertently killed an opponent in a fight did not deserve a criminal trial. Even in the early eighteenth century some inhabitants of Amsterdam were prepared to help an 'unfortunate manslaughterer' flee the town ${ }^{30}$. In any case, we should not assume that the moralist writers were ignorant 
about legal practice. Willem Teellinck, for example, had studied law in Leiden and had obtained a doctor's degree in law from the University of Poitiers in France ${ }^{31}$.

Godefridus Udemans (c. 1580-1649) entered the sample with two works, Spiritual Rudder and Practice, dated 1655 and 1658, respectively ${ }^{32}$. Udemans, Reformed minister in Zierikzee, became notorious in the 1640s after launching a debate about the fashion of long hair for men ${ }^{33}$. His Practice deals mostly with the ten commandments, among which the sixth. Udemans distinguishes four main categories of homicide: with the mind (anger, cruelty, hostility, etc.); with one's facial expression (looking angrily at someone, laughing at him, shaking one's head or showing a wide open mouth); with words (scolding, betraying someone, etc.); by deeds. The fourth category is divided into twelve subcategories: premeditated homicide; homicide during a fight; the duel; suicide; lightly exposing oneself to danger; pardoning intentional homicide; mutiny and riot; to treat someone cruelly under the guise of the law; to dishonor someone by a deed; to mock the deaf or the blind; to mistreat, abandon or kill young children; to irritate someone. This is an elaborate list indeed, giving body to his predecessors' argument that every conflict which may ultimately result in killing falls under the sixth commandment.

About the duel, Udemans is certainly more elaborate than his predecessors. In both works discussed here, for example, he gives a definition of this custom: «when two persons, resorting under one and the same public authority, challenge each other to fight with their fists, body to body.» That is in Practice. In Spiritual Rudder the definition is identical, but he adds «from pride and lust for revenge,» in order to underline the duel's abject nature. Is this emphasis on a fist fight just Udemans' idiosyncracy, stemming from an ignorance of actual practice? Or should we conclude that, until at least the middle of the seventeenth century, soldiers in the Dutch army mainly fought the popular type of duel without swords and that Udemans' predecessors, too, primarily had that type in mind? Whatever was the case, some defenders of the custom argued that David's battle with Goliath was also a duel. Udemans has no mercy for this argument, pointing out that David fought the leader of the enemy not out of lust for revenge but on God's orders. Udemans is equally impatient with the argument that anyone who refuses a challenge will be considered a coward and lose his honor. That idea is no more than the devil's suggestion, he says. Although Udemans recognizes the importance of honor, especially for officers, to a certain extent, he warns that the fate of the soul should always be one's primary concern. In Spiritual Rudder he illustrates this with 'a rhyme of our ancestors': «Goods lost, is something lost/ Blood lost, is lost more/ Courage lost, is lost much/ Honor lost, is lost even more/ Soul lost, is all lost» ${ }^{34}$.

The name of Johann Ludwig von Wolzogen (1676) betrays that he was not Dutch, but the remarks inserted by his translator, who identifies himself only as L.W., justify the inclusion of the book in the series under scrutiny here. Von Wolzogen (born 1598) had been Freiherr of Neuhausen in Austria, but he was obliged to leave that country when he joined the Polish Brethren (or Socinians). He established himself in the Dutch town of Amersfoort and counted as a leading figure among the Polish Brethren. His son Louis, born in Amersfoort in 1633, became a minister of the Walloon Reformed Church and later a theology professor, but the orthodox supporters of Voetius heavily attacked him. It is of course possible that this son was our translator (he had dropped the "von» from his name! $)^{35}$. Whether or not this was the case, the author had decidedly pacifist leanings, whereas the translator was somewhat less radical on this point. The latter 
praises the Dutch Mennonites, for example, for having cooperated in the fortification of city walls during the French invasion of 1672, thereby showing their obedience to the authorities. On the issue of an attack by criminals, the translator also shows himself more permissive than the author. Von Wolzogen had recommended relatively peaceful measures like holding your attacker by the hand. The translator, speaking of «some malefactor or half-drunk person who rushes into my house with a knife or a sword» in order to kill the wife, children or a friend, allows his readers to disarm the intruder and throw him to the floor. L.W. further specifies that it is permitted to ward off an attacker with a stick, provided that the defender has no intention to seriously injure him and has prayed to God for strength. The defender may hit his attacker on the arms, legs or body and if the latter is hurt unintentionally, that is acceptable. In a later passage, the translator agrees with the author that high-ranking persons are allowed to bear a saber, which is anyway uncommon in the Netherlands. The translator adds that bearing a saber is comparable to taking a huge stick with you on a walk, with which people sometimes forcefully hit and injure an attacker. The two passages about sticks conform to the actual practice of respectable people threatened by someone with a knife, as evidenced by court records of the late seventeenth and early eighteenth centuries ${ }^{36}$. Von Wolzogen's translator says that he wished to elaborate on this point in order to «reassure some tender consciences who have a problem with this» ${ }^{37}$.

Three years later, Jacobus Hondius published another register of sins, explicitly directed at all members of the Reformed Church. The author was minister in Hoorn and the dedication by a colleague of that town depicts Beelzebub's desperation at seeing the door of his castle rammed constantly by Hondius' merciless attacks. Despite his colleague's enthusiasm, the book contains few arguments about violence not already covered by his predecessors. For example, Hondius literally copies Voetius' remark about people who hide manslaughterers from the prosecuting officer. Everyone guilty of homicide should be punished by death, Hondius emphasizes, and the authorities should not tolerate that killers seek refuge in sanctuaries. Novel passages concern the sins of those who promote or enjoy cock fights and the violence of women, which Hondius finds especially inappropriate ${ }^{38}$. Finally, his reference to dueling explicitly mentions seconds, which suggests that he has the official duel in mind ${ }^{39}$. More popular than Hondius' book was The Golden Mirror by his contemporary, Jacob Mayvogel, the oldest extant edition dating from 1680. It includes a discussion of the sixth commandment, offering no new themes ${ }^{40}$.

The next register of sins was published by Jacobus Koelman (1631-1695) in 1690. It is in fact a new revision of Van Houten and Voetius, of whom Koelman had been a student. He equally detested Cartesian philosophy and his interest in Puritanism is evidenced by his translation of Francis Rous' The Heavenly Academie. His career, however, was less succesful than that of his teacher. As minister in Sluis, Koelman was deposed by the town's magistrates, after which he travelled around the country as a preacher at conventicles ${ }^{41}$. His revision of Voetius consisted mostly of adding sins against the second commandment, which leaves little of interest for our discussion. Once more we read the same warning about people who hide manslaughterers from the prosecuting officer, but it would be unwise to infer from this a continuous frequency of the practice. A new item concerns the inclusion, into the group of sinners against the sixth commandment, of merchants who store grain in order to sell it for a high price during a famine. They cause people to starve ${ }^{42}$. 
24 As an extra, let us consider two works from the early eighteenth century, because they indicate a change of tone. After 1700 the genre of straightforwardly Christian, moralist works by ministers seems to give way to a more philosophical type of discourse, still religiously colored though. Campegius Vitringa (1659-1722), professor of theology in Franeker, published the work under consideration originally in latin. His translator, Johannes d'Outrein, was a minister there for three years and he boasted to have presented Vitringa with a number of refreshing teachings. The book (1717) contains one interesting passage. It is better to avoid all political and religious conflicts and party struggles, the author assures us, unless intervention is absolutely necessary for the honor of God, or «our honor or rights»" ${ }^{43}$. Personal honor, it seems, is partially rehabilitated here, when compared to the outright condemnation it received from most of the ministers.

This shift from a purely religious to a religious-philosophical discourse is also apparent in the 1720 work of Benedictus Pictet (which is why it is considered here; although the book was published in Leeuwarden, it is by a foreign author and the translator has inserted no remarks of his own). Pictet (1655-1724) was professor and minister in Geneva and the translator, François Halma, was the official printer for the Estates of Friesland ${ }^{44}$. The philosophical tenor is apparent, for example, when the author poses the question why it is sinful to mutilate someone, even though the sixth commandment only says «thou shalt not kill.» For the Dutch ministers this extension of the commandment's coverage had been self-evident; they never posed it as a logical problem. Pictet solves it with the argument that a mutilated person is no longer able to work and withers away in destitution, which is almost equal to death. This leads him to the same conclusion as the ministers before him: All anger and fighting which may result in homicide falls under the sixth commandment. Outside it - and here, too, Pictet is in agreement with his predecessors - is everything which serves to maintain the state's monopoly of violence, such as the executioner's activities. It is also OK to kill animals, which God has granted us for food.

26 An illuminating passage concerns honor. In worldly affairs, Pictet explains, the epithet of 'man of honor' is bestowed upon almost everyone except notorious rogues. But this is not quite right. A really honorable man is pious and virtuous and behaves well. A person should prefer to live as a really honorable man, rather than just have the reputation of one $e^{45}$. Although Pictet refers to Cicero in this context, we may conclude that, within the framework of European cultural history, he takes a giant step in the direction of the spiritualization of the concept of honor ${ }^{46}$. Whereas his religious predecessors rejected personal honor outright, a rejection which remained unacceptable to many 'people of the world,' Pictet tries to transform the notion of honor, so that it becomes potentially acceptable for both sides.

\section{Synods and Classes: Violent Church Members and Ministers}

27 Whereas the moralists spoke about personal conduct in general terms, the provincial and regional synods dealt with concrete incidents and practical concerns. Thus, their records form a useful complement to the sources discussed so far. A minor disadvantage is that we miss the occasional dissenter voice and only learn about the views of the Reformed Church. Remember also that the records have been published in 
large majority for the period 1570s-1620 only. The business of these church meetings, in so far as it relates to violence, can be divided into three broad categories: incidents in which members and sometimes even ministers were involved; discussions about reconciliation and pardoning in cases of homicide; and admonitions to the secular authorities. The first category is closest to the concerns of the moralists, so it is convenient to begin with it.

The synods dealt with institutional matters, regulations and policies, rather than issues of discipline. Censuring the behavior of individual members was a task for the consistories. As Roodenburg (1990) has demonstrated for Amsterdam, members were censured among other things for violent conduct, and studies of consistorial discipline in other places will no doubt reveal more cases. Handling the offenses of individuals could raise institutional issues though. When a minister misbehaved seriously, he might be removed from office. The behavior of ordinary members made it to a synod when they wanted to marry in church, for example, or when a parish was unsure how to react to it. The synod protocols contain a fair number of short notes about members involved in fights and about parishioners as well as preachers with a bad way of life which included quarrelling, threatening and fighting. These notes are relatively uninformative, so let me restrict myself to the more telling examples.

The oldest recorded case took place in 1587 in Klundert near Breda, which then belonged to the classis of Dordrecht. It was noted that brother Willem Claeijsz had committed a homicide, in self-defense though. Everyone testified that he was not to blame. He had been withheld from Communion nevertheless, but it was now decided to re-admit him, if the court confirmed his innocence. When it did so, Claeijsz still had to apologize and ask forgiveness from the parish community ${ }^{47}$. Apparently, even killing in self-defense made a Church member suspect, possibly because it suggested that he was unwilling to avoid the company of hot-tempered persons.

30 Minister Henricus Bernardus of Goutum in Frisia was also suspect. The Frisian synod removed him from office in 1591, because he had allegedly committed adultery and homicide in Groningen, and that after renouncing Catholicism. Twelve years later, however, Bernardus was rehabilitated when it turned out that the rumors about homicide were untrue and that, although guilty of adultery, he had committed this offense "while still standing in Popery» and unspecified mitigating circumstances applied $^{48}$. The charges against Gerardus Verstraten, on the other hand, were wellattested. The synod removed this minister of Ijsselmonde in Holland from office in 1592 , because he was quarrelsome and drank too much. On a Sunday after his second sermon he had visited a children's party and become so drunk that two women were obliged to take him home. Several quarrels were mentioned as well, and Verstraten had once drawn a knife against one of the elders. The fact that this preacher was found unrepentant sealed his fate ${ }^{49}$.

31 The Drente synod of 1603 dealt with a minister who had committed a homicide, albeit once more in self-defense and before he took office. The local court and several witnesses confirmed Hermannus Alers Swollensis' innocence. Nevertheless, the synod wanted to remove him from office, «in order to prevent all bits of irritation which might be directed at the Church.» Four years later, however, he appeared to be still in office $^{50}$.

32 A protracted case took place in Hillegom, in mid-Holland, in 1606. On May 27 the question was first raised whether Abraham Stamperius' candidacy for the post of 
minister there should be approved. There was disagreement between the local jonkers and the church about it, but especially scandalous was the «scar in his face.» Although he claimed, the synod noted, that he got it while attempting to separate two knife fighters, without being a participant in the fight himself, this was not the first time that he was found «in such places» (presumably places frequented by knife fighters). While still a student, moreover, he was a notorious «nightwalker»; several of his landladies had been obliged to open the door for him late at night. When questioned himself, Stamperius came up with an elaborate story, explaining that one night while he and some friends were returning home, his company got into trouble with another group, whereupon one of the others, mistaking Stamperius for the man who had injured him, gave Stamperius a cut in the face in retaliation. The candidate's father, present to testify, even claimed that his son had in fact saved the lives of two persons. His scar should therefore be considered a mark of honor. The last witness was no one less than Gomarus, the future leader of the Church's orthodox Calvinist wing, whose theology classes the candidate had taken. Gomarus had heard from twenty other students that Stamperius «has received this injury in an honest manner, although paired unequally, which he was unable to better.» It is not entirely clear what Gomarus meant by "paired unequally»; he may have meant that it was not a one-on-one fight and hence unfair, although his student was not to blame for this. Gomarus, too, considered Stamperius' scar a mark of honor. The case was discussed at several subsequent meetings and Stamperius was apparently also a (welcome) candidate in Zierikzee. On September 16, the Hillegom parish agreed to call upon someone else ${ }^{51}$.

Two more cases of violent preachers were handled by the Drente synod, with the first hearings occurring in 1608 and 1611, respectively. The minister of Schoonebeek had committed an "accidental manslaughter» against an East Frisian skipper. A report from the magistrates in Leeroort was received in 1611 but not inserted in the protocol. Although the minister should be removed from office, the community at Schoonebeek protested that, being in a remote place, they would have trouble finding someone else and that their preacher was poor and had young children. He was allowed to stay in office for another year, on the condition that he behaved irreproachably ${ }^{52}$. The second case involved a preacher who was attacked by a vagabond while lying in bed. To defend himself, the preacher had injured his assailant with an axe. It was noted that this minister had already been suspended for some time and no other punishment was thought necessary. Defense against a vagabond, apparently, was much more a matter of course than against settled people.

This series concludes with a somewhat different case. In 1615 the consistory of Breskens in Zeeland presented the problem of a man who had committed two homicides and wanted to marry. Self-defense was not mentioned this time, but apparently the killer was free to move. The banns had already been published three times, but was it OK to unite him in marriage with his bride? The classis ordered the Breskens preacher to put severe pressure on the prospective bride to renounce her partner. If she refused, the man ought to petition the secular authorities for permission to marry and, if he was successful, the two could be married in $\operatorname{church}^{53}$.

There is no point in subjecting these cases, together with the uninformative incidents not discussed here, to a quantitative analysis. It is clear nevertheless that the Reformed Church faced a problem of unruly adherents in its early years and that violence was one of the sins these persons were reproached for. Remarkably, this group included 
ministers and in the case of one of them, it was considered of crucial importance to know whether he had committed his sins "while still standing in Popery.» This alerts us to the fact that, for many people who lived through the Reformation, it was not just about establishing a new creed but a reform movement affecting the existing Church as a whole, highlighted by the experience of Catholic priests turning into Protestant preachers. For the godly among the Protestants, the bad conduct of some preachers was a remnant of Popery. This idea was not completely unfounded, since there is some evidence for the violence of the pre-Reformation clergy in Europe. Among Finns who travelled to Rome between 1450 and 1521 to obtain absolution for manslaughter or assault, Kirsi Salonen found a relatively large number of priests. Priests were perpetrators as well as victims. Salonen hints that this indicates the close integration of the clergy into lay society; they took part in conflicts and fought with knives just as easily as laymen $\mathrm{did}^{54}$. David Potter is more explicit in a study of pardon letters from Picardy in the second quarter of the sixteenth century. Noting the substantial number of priests who requested pardon for homicide, he emphasizes their participation in community life and activities such as drinking in taverns and common meals. Here, too, priests were killers as well as victims of killing ${ }^{55}$. As the Counter-Reformation led to a neater separation of the Catholic clergy from the lay community, we may assume, in the absence of concrete data, that the phenomenon of violent priests soon disappeared ${ }^{56}$. Likewise, the problem of violent ministers appears to have been serious during the first generation of Protestantism only, because synods after 1620 no longer refer to them.

\section{Synods and Classes: About Reconciliation and Pardon}

This is different in the case of pardons for killers. Moreover, regarding the question of how to handle homicide, the Reformation made a radical break with Catholic attitudes. For one thing, the ritual of reconciliation (zoen) between the families of victim and killer became much less elaborate and fewer persons were involved in it. Whereas fifteenth-century zoenen had included endless prayers and numerous prostrations, by 1600 only the killer himself briefly knelt while asking forgiveness ${ }^{57}$. De Waardt considers the Reformation as the principal factor in this change, even though the records discussed below do not designate the zoen as Popish. In any case, the changes in reconciliation ritual formed part of a broader transformation leading to the full criminalization of homicide.

In Holland this transformation was a long, drawn-out process which started at least as early as the mid-fifteenth century and its completion has not been fully documented yet by historians. For a long time, reconciliation had been the principal alternative to (continuing a) vendetta and as such it enjoyed the favor of the authorities. Reconciliation served to prevent the criminal prosecution of homicide ${ }^{58}$. If a court did take action after a killing, the prosecutor often reached a monetary settlement with the perpetrator, who received no further punishment. In 1544, however, the Habsburg government issued an ordinance aiming at a more systematic prosecution of homicide. Since then, reconciliation could in principle not prevent criminal prosecution, but it served as a necessary precondition for obtaining either a pardon or the suspension of a sentence ${ }^{59}$. The criteria for considering a manslaughter as excusable, however, continued to be rather permissive. In the early Republic, the fragmentation of 
jurisdictions contributed to the image of impunity for homicide, because a default trial usually ended in banishment: the killer forfeited his life if he returned, but only to that particular jurisdiction. Official reconciliations appear to have become infrequent by the second quarter of the seventeenth century. In 1631 Hugo Grotius, although claiming that zoenen were concluded daily, nevertheless called them a remnant of ancient law ${ }^{60}$. The last reconciliation mentioned by De Waardt occurred in 1642, but he concludes from lawyers' manuals that the procedure remained in force throughout the Republican period. In the later seventeenth and eighteenth centuries, however, it mainly served to establish financial compensation for the victim's family ${ }^{61}$. The procedure for the suspension of a sentence also remained in force throughout the Republican period, but it was very infrequent since the early seventeenth century ${ }^{62}$. From then on, the principal routes of escape from criminal prosecution for homicide, apart from physical flight, were to receive a pardon from the Prince of Orange or to be admitted to one of the sanctuaries within the Republic's territory ${ }^{63}$. Both possibilities were in practice restricted to only a few killers.

The first time that the zoen was recorded in a synod protocol, the issue had been raised incidentally. In 1583 the reverend Paschasius Gerhardi Pensaert had sent a written excuse for the April 26 meeting of the Dordrecht classis. The reason was that he had to be present at a reconciliation after a homicide. The inappropriateness of this excuse was noted immediately: ministers should not be present at such reconciliations at all. The classis decided only to rebuke Pensaert, because he had acted from onbedachtheyt (ignorance/ impulse). At the next meeting which he attended, in September, the question whether Church officials were allowed to play a role in zoenen was raised anew. The matter had apparently not been settled yet: two times a delay of decision was recorded and that was all for the Dordrecht classis ${ }^{64}$. Six years later however, the Gouda synod set the course toward ecclesiastical abstinence. It was decided that preachers were allowed to admonish their flock toward peace and forgiveness, but they were forbidden to meddle into «the political handling and reconciliation, which occurs in cases of manslaughter» ${ }^{65}$. Yet, the Gorcum synod of 1595 was hesitant again. The hypothetical case was discussed of a Church member who had committed a homicide, had been admonished about it, had admitted his guilt and promised a Christian improvement of his way of life and was prepared to repeat this publicly before his parish, but those intent on revenge were still reluctant to forgive him. How should the Church react? Those present at the meeting did not really know, only noting that the activities of the secular authorities should not be thwarted ${ }^{66}$.

The synod of Leiden in 1600 brought further clarity. It was noted that there were Church members who desired the presence of a preacher at a zoen, among other things as a witness to the financial settlement. This was, according to the synod, incompatible with the task of Church officials, which consisted of punishing killers and exhorting the magistrates to be diligent in their office. Preachers were only allowed to cautiously try to calm down the parties involved, without contributing to the killer's effort to obtain a pardon or slow down justice in any way ${ }^{67}$.Clearly, the Church people were in a doublebind situation on two points. First, they increasingly rejected homicide reconciliations, but neither did they want to foster revenge. Second, they resented the fact that the courts offered ways to escape the death penalty, but this resentment should not lead to disobedience to the secular authorities. 

The parish of De Lier had elected a deacon who once had participated in a zoen after a homicide. However, he had only spoken in order to pacify the parties and had not contributed to the procedure of landwinning. He himself belonged to the victim's relatives. The classis confirmed that the Leiden synod had allowed «mediation in order to pacify the parties» but forbidden helping a killer to get landwinning. Although the deacon had done nothing wrong, he was warned to act carefully in the future ${ }^{68}$. Landwinning had meant various things throughout the centuries. The common element was that a person «won back the land» (his native or residential region), from which he had been excluded by a judicial order and which he was temporarily or permanently allowed to re-enter unpunished. In the later middle ages landwinning primarily referred to the lifting of a banishment for manslaughter, whereas in the sixteenth century the Court of Holland granted this privilege as de facto pardon «in cases of justifiable homicide or just a light transgression of the rules for it ${ }^{69}$. Reconciliation with the victim's relatives was a necessary condition for obtaining landwinning. In 1609 the Maassluis classis interpreted the Leiden decision in the following way: After a homicide an elder was allowed to speak to the parties involved but «only to soften their tempers» and to admonish them to renounce revenge. No Christian, however, was allowed to engage in any activity aimed at obtaining a pardon from the secular authorities ${ }^{70}$.

meantime, concrete cases had been handled by several classis meetings in Holland. In 1605 the Warmond parish presented the case of Justus Bouleus' son. He had been barred from Communion for twenty-two years on account of a homicide «innocently committed» in Leiden. No judicial punishment had apparently followed and neither had there been a zoen. Bouleus was repentant and witnesses testified to his good behavior, but if he did not reconcile with the victim's relatives, bad rumors would still circulate. The problem was that the relatives demanded a much higher sum than Bouleus, a poor artisan with a wife and children, could raise. He had told the relatives many times that their price was too high, but that he wished to do everything within his capabilities in order to satisfy them. The brothers of the classis believed in his good faith, but they wished to prevent any bad rumors. They advised Bouleus to entreat the relatives once more, in the presence of two witnesses, to moderate their claims. A written protocol of this event should be drawn up and be read to the parish community from the pulpit ${ }^{71}$. Obviously, although Church officials were forbidden to participate in a zoen, reconciliation after a killing in self-defense was still considered important, or at least the Church wanted to prevent any rumors that members present at the Communion meal were in mutual enmity.

The questions raised by the Enkhuizen parish in 1606 were probably all occasioned by actual incidents. Complaining about frequent killings against which the Estates ought to employ all means available, the parish asked whether a Christian was allowed to accept money in any way in case of a zoen for manslaughter. The answer was straightforward: Whoever tries to arrange for a zoen, always does so in order to facilitate obtaining a pardon from the authorities. Therefore, no one is allowed to cooperate in a zoen by taking money. One may only accept it when the authorities have imposed this on the other party as a reparation or as assistance for the widow or children of a homicide victim. The Enkhuizen parish finally mentioned that a lawyer, who was a Church member, intended to demand from the Court of Holland that it stop a public attorney from prosecuting against a killer. As a reply they were told that the 
lawyer was not allowed to breach his professional oath and that the parish should act as it saw fit $^{72}$. In the same year the parish of Mijdrecht in Utrecht complained about another means of preventing official prosecution. The bodies of homicide victims were dragged to the local cemetery, which was considered a sanctuary where the court could not have them inspected ${ }^{73}$.

The Church's actions against reconciliation and pardon since the 1620 s will be discussed below. At the end of the period under review in this section, the issue came up again in Utrecht and Holland. In 1619 the churchmen of Utrecht complained that the bodies of homicide victims were laid unburied in church, until a zoen with the relatives had been made ${ }^{74}$. At the Gouda synod of 1620 two classes complained that zoenen for homicide were done in church. This is rather remarkable, in view of the churchmen's hostility against the practice for more than a generation. Performing the ritual in church was called a desecration and the wardens were authorized to call upon the strong arm of the secular authorities, if need be, in order to prevent this ${ }^{75}$.

\section{Synods and Classes: Admonitions to the Secular Authorities}

The Church's admonitions to the secular authorities, urging them to show a tough face to offenders guilty of homicide, were numerous and it would be futile to mention all recorded instances. The earliest I found occurred at a meeting in Leiden in May 1585. The delegates wished to bring several issues to the attention of

the Estates of Holland, among which their concern that remission for manslaughter was granted lightly ${ }^{76}$. Ten years later the classis of Enkhuizen complained about the procedure of landwinning. Even intentional killers, it was said, regularly obtained it and they proudly walked around in their town or village afterwards. A complaint with the Estates was in order, the more so since no lower court but only the Court of Holland had the authority to grant landwinning ${ }^{77}$. The churchmen apparently found no willing ear, because they decided to approach the Estates again about this issue the next year. This time, the list of abuses included the toleration of Popish superstitions and the «impunity of intentional manslaughterers» ${ }^{78}$. At Gorcum in 1606 the churchmen decided to petition both the Estates of Holland and Prince Maurice. They said, in paraphrase: 'Please, prevent safe-conducts for manslaughterers by local lords, who do not even have the right to grant this; don't believe those criminals who seek remission for homicide with untrue stories; renew the placards against homicide; at dances and drinking bouts, especially at rural fairs, a murder or manslaughter is committed almost each time ${ }^{79}$. The second of these four complaints shows the Gorcum synod anticipating Natalie Davis' judgment that the archives contained a lot of fiction by almost four centuries ${ }^{80}$.

Provincial synods outside Holland were not always so active on the issue under scrutiny, but the available evidence allows us to conclude nevertheless that the Church's concern for the judicial prosecution of killers was widespread in the Dutch Republic. Although the indexes of the Gelre and Zeeland synods yield little of interest, Overijssel synods admonished the authorities a couple of times to punish manslaughterers and Frisian synods did so even more frequently. At the provincial synod of Groningen in 1616 the grietmannen (local judges and administrators) were admonished not to grant safe-conducts to killers. The next year the synod presented a 
petition which complained, among other things, that a number of persons who had fled or been banished from the Groningen countryside for homicide, now lived just across the border in Frisia ${ }^{81}$.

\section{Synods in Southern Holland after 1620}

For the period 1620-1700 we have to be content with the protocols of the regional synods of Southern Holland only. These protocols first referred to violence in 1623. The synod decided to exhort the authorities into action against sins such as adultery, profanation of the sabbath and homicide. The churchmen were also concerned about «too easily concluded reconciliations for manslaughter»" ${ }^{82}$. Eight years later, homicide was again mentioned in the context of other vices, including cursing and swearing this time. The implicit objection was that visiting taverns on Sundays, instead of praying, led to fights and worse. The matter returned very summarily in 1632 and 1633, while in 1635 the synod demanded a renewal of the placards against drawing a knife, because this often resulted in killing. The 1631 entry included a complaint about easy pardons for homicide and «protection» granted to killers by some local lords. It also included the last references to reconciliation in the sources studied. The synod confirmed once more that an unreconciled and unrepentant killer could not marry in church. The formal zoen was said to be concluded in «the temples of the papists» $»^{83}$.

The disappearance of the formal zoen from our records offers an indication for its marginalization, except perhaps as a financial compensation measure, in actual practice, but as stressed before, more research into the criminalization of homicide is needed. The Church's remaining target was the sovereign's pardon, officially granted by the provincial Estates, but with an important role for the Prince of Orange, who was usually perceived as the sole pardoner. In 1637 the synod noted that the Estates had addressed earlier complaints about pardoning with the statement that the matter only regarded His Highness. The procedure was carefully controlled though, with an advice from the Court of Holland, official registration, etc., but it might occasionally happen, the Estates conceded, that His Highness was «abused» (by killers making false statements, presumably). The synod seemed satisfied with this reply. In 1650 the churchmen themselves referred to the procedure as controlled, in the case of civil as well as military persons. The Prince granted pardons to killers from the latter group in his capacity as captain general of the army. The synod merely requested him not to extend his mercy to duelists and other intentional manslaughterers. William II was left little time to pay heed to this advice and no new stadholder was appointed after his death. In 1651 the synod noted that the question of pardons for killers now had to be taken up with the Estates. The principal complaints, however, came from the brothers of Breda, in particular about homicidal soldiers. The synod assisted the Breda brothers in drawing up a petion to the Council of Brabant and the next year it was reported that the governor of Breda had promised to be vigilant ${ }^{84}$.

48 A curious entry in 1656 stands apart from the usual themes dealt with since the 1580 s. The protocols sometimes ended with excerpts from other synods and in this year they included article 73 of the provincial synod of Groningen: «About the objection concerning the disease of homicidalness and the discipline exacted from Church members who use the knives of manslaughterers as a remedy against this disease, our judgment is that this is a diabolical deception and a horrible superstition.» People who 
are not firm in the word of God ought to be warned against this belief ${ }^{85}$. It is a pity that this is all we learn. Did certain people really believe in a disease of «homicidalness» or was it meant metaphorically? The magical remedy, reminiscent of similar gallows lore which was especially widespread in the German lands, suggests the first ${ }^{86}$. Generally, the Republic's eastern provinces remained 'enchanted' for a much longer time than urbanized Holland. The reference may either mean that in Groningen homicide still was so common that it was considered a disease that could befall everyone, also Church members, or, alternatively, that it had become uncommon and that those marginal people who were still prone to aggression were considered sick persons.

In the same year, the synod of Southern Holland wrote a letter to the provincial Estates. It included the obligatory allusion to the wrongful toleration of intentional manslaughterers, but the main focus was on dueling. God was desecrated each time when a homicide happened, «especially in one-on-one fights or duels, transported from other provinces to ours, and perniciously appearing to have become very common in our provinces and to be considered an act of honor.» The churchmen did not consider duels honorable at all. Duelists, they noted, intentionally wash their hands in each other's blood; they are more cruel than bears or tigers ${ }^{87}$. From that year on, manslaughter was always mentioned together with dueling. In 1657, for example, the synod expressed its satisfaction that a placard had been issued against manslaughterers and duelists. Some general grievances, not restricted to dueling, remained nevertheless. In 1658, for example, the synod complained that many killers fled to sanctuaries or to places where the local court had no criminal jurisdiction. In a manner reminiscent of the Groningen synod some forty years earlier, the churchmen of Southern Holland now pointed at killers who were walking around freely across the provincial border, even if they had committed their homicides in places adjacent to that border, from where they could be seen. Complaints about dueling, sanctuaries and impunity were repeated in 1659 and $1660^{88}$. Note that the reference to killers staying just across the border referred to fugitives who had been tried by default, not to zoen or asylum. In Holland, the usual sentence in a default case for homicide was a banishment from the province on penalty of death if the culprit returned. The obvious remedy, which the synod did not propose, would have been to change this into a banishment from the entire Republic.

The synod remained silent on the subject of violence until 1678. In that year it was noted that duels and homicides were getting frequent again, especially within the military. Action from the Estates and the Prince was necessary. The next year the synod's delegates reported that they had spoken to the president of the Court of Holland, who had been willing to take action, but only if they would present evidence of «notorious recent incidents.» Again a year later the delegates admitted, when questioned at the synod, that they had been unable to find evidence of recent incidents. Despite this, it was again noted that duels were very common, especially among military men, and that a petition concerning this evil should be sent to the Estates and the Prince. In 1684 the synod could finally express its gratitude to the Prince for the new placard against dueling. The churchmen briefly repeated this during the next two years ${ }^{89}$. From then until 1700 , the closing year of the published edition, the Southern Holland synod did not concern itself with anything related to violence. The conclusion reached by Van Weel (1977) almost thirty years ago, that the synod's efforts around 1680 primarily concerned the military duel, appears correct. 


\section{Conclusion}

5

Protestant moralists and Reformed synod meetings in the Dutch Republic in the late sixteenth and seventeenth centuries showed a remarkably consistent attitude. They strongly disapproved of interpersonal violence and they advocated the full criminalization of homicide. In particular, Calvinists rejected the traditional procedure of private settlement and reconciliation (zoen). They might have adopted this procedure and included it in their own new repertoire of reconciliations among Church members, but they chose not to. Instead, Reformed synods exhorted the secular authorities to have no mercy on killers and murderers. The courts should prosecute them all and acquit only the tiny minority who really had had no other choice in order to save their lives. As for the Church's own reaction, even those who clearly had acted out of self-defense were not considered entirely clean: where there was smoke, there was fire. Occasional remarks from the moralist writers about judicial prosecution betray that they shared the synods' attitude. At about the time when judicial prosecution of homicide had become firmly established, Church meetings concentrated their attention on the duel. It is harder to ascertain exactly how much the shift from private settlement to the full criminalization of homicide owed to Church pressure. This shift also occurred in German territories and Scandinavia ${ }^{90}$. In France and the adjacent Burgundian lands, the number of pardons for homicide decreased sharply during the first half of the seventeenth century ${ }^{91}$. Whether or not Lutheran and Catholic opinions influenced these developments in the respective countries remains unclear.

Next to homicide, the moralists unequivocally condemned every form of interpersonal violence and the anger and conflicts that might lead to it. They equally rejected the honor code involved, at least up to 1700 . For the moralist writers, the sixth commandment covered a broad spectrum of social action, including fighting, quarreling and every kind of discord. And they saw this violence as an integral part of a licentious way of life, which equally manifested itself in drunkenness and unchastity. On this issue, there was hardly any difference between the orthodox and the not so orthodox, nor between the Reformed and Protestant dissenters (although the latter's voices were few). This consensus is not really surprising. It has been pointed out that the practical toleration of religious diversity and the relative absence of large-scale religious conflict in the Dutch Republic owed a lot to mutual social intercourse. In daily life, adherents of various creeds freely conversed with each other and members of different Protestant denominations read each other's devotional literature ${ }^{92}$. We can now add the rejection of interpersonal violence to this picture of practical consensus. To a large part, the consensus extended to the moralists' views about national defense against the country's enemies. While the moralists condemned private violence, they respected the state's monopoly of violence, and even relatively pacifist, non-Reformed Protestants appeared in agreement with this.

Whereas the Protestant consensus about fighting and killing is relatively unsurprising, the Reformed Church's radical rejection of reconciliation presents a problem of interpretation. Why should it have been this way? One possible answer leads to the Calvinists' predilection for the old Testament and its consequences for their views in penal matters. An earlier generation of legal historians attributed the origins of

Crime, Histoire \& Sociétés / Crime, History \& Societies, Vol. 10, n² | 2006 
imprisonment -incorrectly- to this connection. The old Testament, so the argument ran, demanded the death penalty for homicide and other serious crimes, but not for theft, which called for alternative sanctions in case of property offenses ${ }^{93}$. A combination of the first and second part of this argument has Calvinism lying at the root of penal bondage as well as the disappearance of private settlements for violent offenses. Such a thesis would be too simple, because both transformations also occurred in Lutheran and Catholic territories. A second possible line of argumentation revolves around the observation that Calvinists, while cherishing their system of ecclesiastical discipline, wanted to demarcate it strictly from the domain of the secular authorities. In fact, they wished to bolster the power of the authorities in specific areas. Remember that the moralists' definition of the duel accorded primacy to the notion of the state's monopoly of violence and the need to maintain it and direct it towards outside enemies. And yet, this type of argument perhaps attributes a too methodical program vis-à-vis the state to the Calvinists. In any case, they frowned upon the judicial procedure of landwinning at a time when it was perfectly legal.

54 A third possibility is that the Reformed preferred reconciliation, but not for the sort of people who were likely to be involved in a zoen. Those people, the Reformed thought, were just as bad as the killers whose guilt they purported to wash away. With that possibility, the paradox of the Calvinist attitude becomes one in the literal sense of the word: only a contradiction at first sight. Some people, the churchmen may have thought subconsciously, ought not to be reconciled - with others, with the parish community, with God. In this way, the Calvinists created a dividing line between those who could be saved and those who did not deserve to be saved. The latter were marginalized. If that argument makes sense, it implies that the Calvinists, with all their rhetoric about fornication, adultery and lack of moderation, counted homicide as the most serious evil.

\section{BIBLIOGRAPHY}

Andrew, D. T., The code of honour and its critics. The opposition to duelling in England, 1700-1850, Social History, 1980, 5, pp. 409-434.

Baardt, P., Deughden-spoor. In de on-deugden des werelts aff-ghebeeldt, Leeuwarden 1645.

Beeke, J. R., Assurance of faith. Calvin, English Puritanism and the Dutch Second Reformation, New York etc., Peter Lang, 1991.

Berg, J. van den, De Engelse puritein Francis Rous, 1579-1659, en de vertaling van enkele van zijn geschriften in het Nederlands, Zeventiende Eeuw, 1985, 1, 1, pp. 48-66.

Billacois, F., Le duel dans la société française des XVI Paris 1986.

Boomgaard, J., Het Amsterdamse criminaliteitspatroon in de late middeleeuwen, in Diederiks, $\mathrm{H}$. A., Roodenburg, H. W. (Eds), Misdaad, zoen en straf. Aspekten van de middeleeuwse strafrechtsgeschiedenis in de Nederlanden, Hilversum, Verloren, 1991, pp. 102-119. 
Boomgaard, J., Misdaad en straf in Amsterdam. Een onderzoek naar de strafrechtspleging van de Amsterdamse schepenbank, 1490-1552, Zwolle, Amsterdam, Waanders, 1992.

Brioist, P. et al., Croiser le fer. Violence et culture de l'épée dans la France moderne, XVI ${ }^{\mathrm{e}}$-XVIII ${ }^{\mathrm{e}}$ siècles, Seyssel, Champ Vallon, 2002.

Burke, P., Popular culture in early modern Europe, New York etc., Harper \& Row, 1978.

Classicale Acta, 1573-1620.

Vol. I: Particuliere Synode Zuid-Holland, Classis Dordrecht, 1573-1600 (ed. van Dooren J. P., RGP, kleine serie, nr. 49), Den Haag 1980.

Vol. II: Particuliere Synode Zuid-Holland, Classis Dordrecht, 1600-1620; Classis Breda, 1616-1620 (ed. Roelevink J., RGP, kleine serie, nr. 68), Den Haag 1991.

Vol. III: Particuliere Synode Zuid-Holland, Classis Rotterdam en Schieland, 1580-1620 (ed. Bouterse J., RGP, kleine serie, nr. 69), Den Haag 1991.

Vol. IV: Provinciale synode Zeeland, classis Walcheren, 1602-1620; classis Zuid-Beveland, 1579-1591 (ed. Bouterse J., RGP, kleine serie, nr. 79), Den Haag 1995.

Vol. V: Provinciale synode Zuid-Holland, classis Leiden, 1585-1620; classis Woerden, 1617-1620 (ed. Kok M. et al., RGP, kleine serie, nr. 88), Den Haag 1996.

Vol. VI: Provinciale synode Overijssel, classis Deventer, 1601-1620; classis Kampen, 1596-1601, 1618-1620; classis Steenwijk/ Vollenhove, 1601-1620 (ed. van Gelderen J. et al., RGP, kleine serie, nr. 90), Den Haag 2000.

Vol. VII: Provinciale synode Zuid-Holland, classis Delft en Delfland, 1572-1620 (ed. Abels P.H.A.M., Wouters A.Ph.F., RGP, kleine serie, nr. 93), Den Haag 2001.

Davis, N. Z., Fiction in the archives. Pardon tales and their tellers in 16th-century France, Stanford, Stanford University Press, 1987.

Emsley, C., Johnson, E. A., Spierenburg, P. (Eds), Social Control in Europe. Vol. 2, 1800-2000, Columbus, Ohio State University Press, 2004.

Evans, R. J., Rituals of retribution. Capital punishment in Germany, 1600-1987, Oxford, Oxford University Press, 1996.

Frijhoff, W., Spies, M., 1650. Bevochten eendracht, Den Haag, SDU, 1999.

Frijhoff, W., Embodied belief. Ten essays on religious culture in Dutch history, Hilversum, Verloren, 2002.

Gaskill, M., The displacement of providence. Policing and prosecution in seventeenth- and eighteenth-century England, Continuity and Change, 1996, 11, pp. 341-374.

Gaskill, M., Crime and mentalities in early modern England, Cambridge, Cambridge University Press, 2000.

Glaudemans, C., 'Om die wrake wille'. Eigenrichting, veten en verzoening in laat-middeleeuws Holland en Zeeland, ca. 1350 - ca. 1550, Diss. Leiden 2003, commercial ed. (forthcoming with Verloren in 2004).

Gijswijt-Hofstra, M., Wijkplaatsen voor vervolgden. Asielverlening in Culemborg, Vianen, Buren, Leerdam en Ijsselstein van de $16^{\mathrm{e}}$ tot eind $18^{\mathrm{e}}$ eeuw, Dieren, Bataafsche Leeuw, 1984.

Herwaarden, J. van, Opgelegde bedevaarten. Een studie over de praktijk van het opleggen van bedevaarten in de Nederlanden gedurende de late middeleeuwen, Assen, Amsterdam, Van Gorcum, 1978.

Heijden, M. van der, Huwelijk in Holland. Stedelijke rechtspraak en kerkelijke tucht, 1550-1700, Amsterdam, Bert Bakker, 1998. 
Hof, W.J. op 't, Everhardus Schuttenius, $\pm 1595-1655$. De eerste vertegenwoordiger van de Nadere Reformatie in Zwolle, Zwols Historisch Jaarboek, 1988, 5, pp. 35-60.

Hondius, J., Swart register van duysent sonden, Amsterdam, 1679.

Houten, J. van, Voetius, G., Biecht-boecxken der Christenen. Dat is een register van de sonden (...). Eertijts t'samen gestelt door Josias van Houten (...) ende nu van nieus uyt-gegeven, oversien en vermeerdert door Gisbertus Voetius, De seste druck, Utrecht 1654.

Ingram, M., History of sin or history of crime? The regulation of personal morality in England, 1450-1750, in Schilling, H. (ed.), Institutionen, Instrumente und Akteure sozialer Kontrolle und Disziplinierung im frühneuzeitlichen Europa/Institutions, instruments and agents of social control and discipline in early modern Europe. Ius Commune, Sonderheft nr. 127, Frankfurt a.M., Vittorio Klostermann, 1999, pp. 87-103.

Jüngen, J. A.G., Doodslagers en hun pakkans in het 16e eeuwse Amsterdam, in Fijnaut, C., Spierenburg, P. (Eds), Scherp Toezicht, Van 'Boeventucht' tot 'Samenleving en Criminaliteit', Arnhem, Gouda Quint, 1990, pp. 79-97.

Karonen, P., A life for a life versus Christian reconciliation, in Lappalainen, M. (ed.), Five centuries of violence in Finland and the Baltic area (Publications of the History of Criminality Research Project), Hakapaino, Helsinki, 1998, pp. 129-195.

Kesselring, K.J., Mercy and authority in the Tudor state, Cambridge, Cambridge University Press, 2003.

Knuttel, W.P.C. (ed.), Acta der particuliere synoden van Zuid-Holland, 1621-1700, 6 vols, Den Haag, 1908-1916.

Koelman, J., Spiegel der wet. Aan de conscientien voorgehouden tot ontdekking der zonden tegen de tien geboden. Nu laatst veel vermeerdert en verbetert, Amsterdam, 1690.

Kruithof, B., Zonde en deugd in domineesland. Nederlandse protestanten en problemen van opvoeding, $17^{\mathrm{e}}$ tot $20^{\mathrm{e}}$ eeuw, Diss., Amsterdam, 1990.

Lake, P., Deeds against nature. Cheap print, protestantism and murder in early seventeenthcentury England, in Sharpe, K., Lake, P., Culture and politics in early Stuart England, Basingstoke, MacMillan, 1994a, pp. 257-283.

Lake, P., Popular form, Puritan content? Two Puritan appropriations of the murder pamphlet from mid-seventeenth-century London, in Fletcher, A., Roberts, P. (Eds), Religion, culture and society in early modern Britain. Essays in honour of Patrick Collinson, Cambridge, Cambridge University Press, 1994b, pp. 313-334.

Mayvogel, J. C., Gulden-Spiegel ofte Op-weckinge tot Christelijcke Deughden (...), Amsterdam, 1680.

Muchembled, R., La violence au village. Sociabilité et comportements populaires en Artois $d u X V^{\mathrm{e}}$ au XVII siècle, Turnhout, Brepols, 1989.

Parker, C., Pilgrim's progress. Narratives of penitence and reconciliation in the Dutch Reformed Church, Journal of Early Modern History, 2001, 5, pp. 222-240.

Pictet, B., De Christelyke zedekunst of schriftuurlyke en natuurkundige grondtregels om godtvruchtig te leeven en zalig te sterven (vertaald uit het Frans door François Halma), Leeuwarden, 1720.

Potter, D., 'Rigueur de justice'. Crime, murder and the law in Picardy, 15th to 16th centuries, French History, 1997, 11, pp. 265-309. 
Reitsma, J., van Veen, S. D. (Eds), Acta der provinciale en particuliere synoden gehouden in de Noordelijke Nederlanden, 1572-1620, 8 vols, Groningen, 1892-1899.

Robisheaux, T., Peasants and pastors. Rural youth control and the Reformation in Hohenlohe, 1540-1680, Social History, 1981, 6, pp. 281-300.

Roodenburg H., Onder censuur. De Kerkelijke tucht in de Gereformeerde gemeente van Amsterdam, 1578-1700, Hilversum, Verloren, 1990.

Roodenburg, H., Spierenburg, P. (Eds), Social Control in Europe. Vol. 1, 1500-1800, Columbus, Ohio State University Press, 2004.

Rudolph, H., Schnabel-Schüle, H. (Eds), Justiz = Justice = Justicia: Rahmenbedingungen von Strafjustiz im Frühneuzeitlichen Europa, Trierer Historische Forschungen, Band 48, Trier, Kliomedia, 2003.

Salonen, K., Violence in Finland in the middle ages and the 16th century in the light of source material from the Vatican Archives, in Koskivirta, A., Forsström, S. (Eds), Manslaughter, fornication and sectarianism. Norm-breaking in Finland and the Baltic area from mediaeval to modern times, Helsinki, Finnish Academy of Science and Letters, 2002, pp. 100-120.

Schilling, H., History of crime or history of sin. Some reflections on the social history of early modern church discipline, in Kouri, E. I., Scott, T. (Eds), Politics and society in Reformation Europe. Essays for Sir Geoffrey Elton on his 65th birthday, London, 1987, pp. 289-310.

Schuttenius, E., Den Christelicken ridder, Kampen, 1628.

Spaans, J., Violent dreams, peaceful coexistence. On the absence of religious violence in the Dutch Republic, Zeventiende Eeuw, 2002, 18, 1, pp. 149-166.

Spierenburg, P., The prison experience. Disciplinary institutions and their inmates in early modern Europe, New Brunswick, NJ, Rutgers University Press, 1991.

Spierenburg, P., How Violent were Women? Court Cases in Amsterdam, 1650-1810, Crime, Histoire \& Sociétés / Crime, History and Societies, 1997, 1, 1, pp. 9-28.

Spierenburg, P. (ed.), Men and violence. Gender, honor and rituals in modern Europe and America, Columbus, Ohio State University Press, 1998.

Spierenburg, P., Violence. Reflections about a word in Body-Gendrot, S., Spierenburg, P. (eds.), Cultures of Violence: Historical Contemporary Perspectives (forthcoming), Ferrara, Sept. 18, 2003.

Spies, M., Satire in een Friese spiegel, in Bremmer, R. H. Jr. et al. (Eds), Speculum Frisicum. Stúdzjes oanbean oan Philippus H. Breuker, Ljouwert/Leiden, Fryske Akademy, 2001, pp. 147-156.

Teellinck, W., Davids wapen-tuygh ende loose der vromer Crijgs-lieden, Middelburg, 1622.

Twisck, P. J., Een schriftelijck tracktaet of verhandelinge van den twist, s.l., 1604.

Udemans, G., 't Geestelyck roer van 't coopmans schip (...). Den derden druck, verbetert ende vermeerdert by den Autheur, Dordrecht, 1655.

Udemans, G., Praktijcke. Dat is werckelijcke oeffeninge van de Christelijcke hooft-deugden (...). Den vijfden druck (...), Amsterdam, 1658.

Venard, M. et al., Histoire du christianisme des origines à nos jours. Vol. 8 (1530-1630), Paris, Desclée de Brouwer, 1992.

Vitringa, C., Korte schets van de Christelyke zeden-leere. Uit het Latijn vertaald door Johannes d'Outrein, Amsterdam, 1717. 
Vrolijk, M., Recht door gratie. Gratie bij doodslagen en andere delicten in Vlaanderen, Holland en Zeeland, 1531-1567, Hilversum, Verloren, 2004.

Waardt, H. de, Feud and atonement in Holland and Zeeland. From private vengeance to reconciliation under state supervision, in Schuurman, A., Spierenburg, P. (Eds), Private domain, public inquiry. Families and life-styles in the Netherlands and Europe, 1550 to the present, Hilversum, Verloren, 1996, pp. 15-38.

Weel, A. J. van, De wetgeving tegen het duelleren in de Republiek der Verenigde Nederlanden, Nederlands Archievenblad, 1977, 81, pp. 282-296.

Westerink, H., Met het oog van de ziel. Een godsdienstpsychologische en mentaliteitshistorische studie naar mensvisie, zelfonderzoek en geloofsbeleving in het werk van Willem Teellinck, 1579-1629, Diss., Groningen, 2002.

Westermannus, A., Christelijcke zee-vaert ende wandel-wech (...), Vijfde editie, Amsterdam, 1631.

Wolzogen, J. L., De werelose Christen, verbeeldende de nature en hoedanigheyt van het Rycke Christi. Door J.L.W. Uyt het Latijn vertaelt en met eenige aantekeningen vermeerdert, s.l., 1676.

\section{NOTES}

3. On the question of how to define violence: Spierenburg (forthcoming).

4. References could be multiplied here, but that would be a bibliographical exercise rather than serve as a helpful context for understanding my argument. Suffice it here to refer to Peter Burke's classic concept of «the triumph of Lent» (Burke 1978) and the recent volumes on the history of social control (Roodenburg, Spierenburg, eds, 2004; Emsley et al., eds, 2004), especially the early modern one.

5. See, for example, Andrew (1980); Billacois (1986). On dueling also several contributions to Spierenburg, ed. (1998) and, most recently for France, Brioist et al. (2002).

6. Roodenburg (1990, pp. 347-361).

7. Lake (1994a, 1994b).

8. Gaskill (1996; 2000).

9. The search system HinT, developed at the University of Amsterdam, forms a good indication. Next to books, it includes journal articles and contributions to collective volumes. Searching for combinations of «Protestant», «Catholicism», «religion» etc. on the one hand, with «violence», «homicide» or «murder» on the other, leads almost without exception to publications about collective violence and civil war in relation to religion, especially during the Reformation and its aftermath. The exceptions, apart from the studies just referred to, are not early modern.

10. The Reformed Church enjoyed various privileges which other denominations, some of which were repressed at times, did not enjoy. Calvinism has always been the dominant doctrine within the Reformed Church and since the 1619 Synod of Dordt it was the only doctrine. Whenever I refer to just «the Church» I mean the Reformed Church.

11. Van der Heijden (1998). Parker (2001) uses sources from the Delft consistory which Van der Heijden had also used, but manages not to refer to her work.

12. On Lutheran parents: Robisheaux (1981).

13. Schilling (1987); for a critique of his views, see Ingram (1999).

14. For further research, books explaining the Reformed catechism, which also treat the 6th commandment, might constitute an additional type of source.

15. van den Berg (1985, pp. 48-50). 
16. Beeke 1991 is devoted entirely to the 'Second Reformation' in England and the Netherlands, but he deals with theological issues only. His index has no entries related to violence or the $6^{\text {th }}$ commandment.

17. The first ed. lists only Pieter Jansz as author (in the preface; on the title page just «P.J.»). The ed. of 1628 (revised by Lammert Pietersz. van Boolswert) has Twisck's full name on the title page. According to the Biografisch Lexicon voor de Geschiedenis van het Nederlandse Protestantisme (BLGNP), Twisck polemicized with Catholics and all non-Mennonite Protestants.

18. Twisck (1604, p. 281).

19. On Teellinck esp. Westerink (2002); also Beeke (1991, pp. 118-138); Hof (1988, p. 35). For an English translation of his works, see http://www.atwhatpricetruth.com/catalog/misc038.htm (May 26, 2004).

20. Westerink (2002, p. 153).

21. Teellinck (1622, pp. 148-150). Quote on p.150: Maer wat wilt ghy dat een cloeck Soldaet sal doen/ wanneer hy daer van een ander uyt-gedaecht wort; sal hy dat soo laten vallen/ ende als een blooden hondt/ zijn steert onder zijn aers steken/ ende door gaen druypen?

22. Hof (1988, p. 36).

23. «Soo moet de crijchsman voor een blooden ende versaechden stomper gehouden worden, die niet van stonden aen sijn leedt ende onghelijck revengeren ende wreecken wil, ende de brandende lonte van sijn wraecgiericheyt op het bussen-pulver van sijn kittelachtighe ende lichtelijck aenstekende herte komen laet, als recht ofte daer in de manlijckheyt ende dapperheyt van een Crijchsmans herte geleghen was» Schuttenius (1628, p. 461).

24. Schuttenius (1628, p. 673).

25. The 5th ed. used here is the only one listed in the Dutch Central Catalogue. According to Frijhoff (2002, pp. 215-216) the first ed. «seems to date from 1611» and the book went through at least 24 editions.

26. «Een Crijgsman grijnst gelijck een Beer,/ Soo haest hy siet een naeckt Geweer,/ (Maer dat ik seyd een naekte Meyd,/ Dat was te groten onbescheyd;)» Baardt (1645, p. 128). This ed. is the only one listed in the Dutch Central Catalogue. On Baardt: Spies (2001).

27. Josias van Houten was a minister in Renesse and Zierikzee. He wrote Korten Wegh of Cathechismus (no eds. in Dutch Central Catalogue; the BLGNP does not mention the year of publication). Voetius revised Van Houten's work, adding material from the Englishman Nicolaes Biefield and Willem Teellinck. Voetius' preface is dated Febr. 1, 1637. The 6th ed. of 1654 is the oldest in the Dutch Central Catalogue. The 7th ed. already appeared in 1656.

28. Frijhoff, Spies (1999, pp. 297-301, 365-369); http://perso.club-internet.fr/vbru/src/ theologiens/ voetius.htm (May 27, 2004).

29. «Item dat volck die het daer voor houden datmen een dief wel mach vast houden maer een dootslager niet, maer soecken die veel liever te verberghen voor den Officier...» Van Houten, Voetius (1654, p. 105). «Vast houden» here refers to a private arrest by citizens, who hand over the criminal to a court servant.

30. Spierenburg in Spierenburg ed. (1998, pp. 123-124).

31. http://www.atwhatpricetruth.com/catalog/misc038.htm (May 27, 2004).

32. Praktijcke is in fact the oldest of the two books discussed here, its dedication dating from 1612. The 1658 ed. consulted is the only one in the Dutch Central Catalogue. The dedication of Geestelijck Roer dates from 1638. I did not consult the $2 \mathrm{~d}$ ed. of 1640 (present in Leiden and Utrecht), nor the reprint of 1965 . This 1655 ed. was revised and extended by the author, which he may have done as well with later eds. of Praktijcke.

33. Frijhoff, Spies (1999, p. 363) (Udemans opposed long hair). About him also: http:// www.ichthustref.nl/hoofdmap_links/lexikontheologen/theologen/Udemans,\%20Godefridus.htm (May 27, 2004). 
34. «Goedt verloren, is yet verloren/ Bloedt verloren, is meer verloren/ Moedt verloren, is veel verloren/ Eer verloren, is meer verloren/ Ziel verloren, is al verloren» Udemans (1655, p. 478).

35. The title page has just «JLW» as author, but the translator's preface lists the author's full name. Information on JLW's Socinianism and year of birth from Hans de Waardt. A.J. van der Aa, Biografisch Woordenboek der Nederlanden and the BLGNP only have an entry for Louis (or Lodewyk). Both entries, practically identical, briefly refer to the father, but as Ludovicus Johannes. Since they mention his Austrian origins and exile because of his conversion to Protestantism (also mentioned in the book's preface), it must be the same person. In the controversy over his orthodoxy, Louis enjoyed the protection of the Estates of Utrecht.

36. See Spierenburg in Spierenburg ed. (1998, pp. 109-111).

37. Wolzogen (1676, p. 189).

38. See Spierenburg (1997, p. 9).

39. Hondius (1679, pp. 99-100). This ed. is the first; the second ed. did not appear until 1724.

40. Mayvogel (1680, pp. 58-61).

41. van den Berg (1985, pp. 59-61). Koelman's views on education are discussed in Kruithof (1990).

42. Koelman (1690, pp. 215-216). This ed. is the oldest in the Dutch Central Catalogue.

43. Vitringa (1717, p. 216) (oldest ed. in Central Catalogue).

44. An ongoing research project concerns Halma. See http://www.kun.nl/pbi/onderzoek.html (January 20, 2004).

45. Pictet (1720, pp. 488-498, 674-676) (oldest ed. in Central Catalogue).

46. On the spiritualization of honor: Spierenburg (1998, introduction, pp. 5-7).

47. Classicale Acta, vol. 1, pp. 235-236.

48. Reitsma/ Veen, vol. 6, pp. 62, 133.

49. Classicale Acta, vol. 3, pp. 141-142.

50. Reitsma/ Veen, vol. 8, pp. 55, 69.

51. Classicale Acta, vol 5, pp. 172-178, 179, 181-182, 182-183, 183-184. Quote on p. 174: «... deselvige quetsure eerlick gekreegen hebbe, hoewel ongelyck gepaert, ' $t$ welck hy niet en heeft connen beteren».

52. Reitsma, Veen (1892-1899, vol. 8, pp. 110, 116, 119, 129, 138-139).

53. Classicale Acta, vol. 4, p. 242.

54. Salonen (2002, pp. 106-110, 116).

55. Potter (1997, pp. 299-300).

56. Venard et al. (1992, pp. 913-920) define both the post-Tridentine clergy and their Protestant counterparts as «hommes à part». They have no references to violence though (and only an index of personal names).

57. de Waardt (1996, pp. 31-33).

58. van Herwaarden (1978, pp. 48-52); Jüngen (1990, pp. 89-91).

59. Boomgaard (1991, pp. 116-117; 1992, pp. 94-99). Suspension of a sentence referred in particular to landwinning (see below).

60. Grotius, quoted in Glaudemans (2003, p. 280).

61. Last reconciliation: de Waardt (1996, pp. 31-32); on the procedure remaining in force: personal information from Hans de Waardt from his research notes.

62. Vrolijk (2004, pp. 113-114).

63. On these sanctuaries: Gijswijt-Hofstra (1984).

64. Classicale Acta, vol. 1, pp. 160, 163, 165.

65. Reitsma, Veen (1892-1899, vol. 2, p. 358).

66. Reitsma, Veen (1892-1899, vol. 3, p. 44).

67. Reitsma, Veen (1892-1899, vol. 3, p. 151).

68. Classicale Acta, vol. 7, p. 417.

69. Glaudemans (2003, pp. 284-287); Vrolijk (2004, p. 129 (quote)). 
70. Classicale Acta, vol. 7, p. 433.

71. Classicale Acta, vol. 5, pp. 152-153.

72. Reitsma, Veen (1892-1899, vol. 1, pp. 392, 394).

73. Reitsma, Veen (1892-1899, vol. 6, pp. 306-307).

74. Reitsma, Veen (1892-1899, vol. 6, p. 436).

75. Reitsma, Veen (1892-1899, vol. 3, p. 458); Classicale Acta, vol. 5, p. 407.

76. Classicale Acta, vol. 5, p. 4.

77. Reitsma, Veen (1892-1899, vol. 1 p. 208).

78. Reitsma, Veen (1892-1899, vol. 1 pp. 215, 219).

79. Reitsma, Veen (1892-1899, vol. 3 p. 249).

80. Cf. Davis (1987).

81. Reitsma, Veen (1892-1899, vol. 7, pp. 288, 313).

82. Knuttel (1908-1916, vol. 1, p. 69).

83. Knuttel (1908-1916, vol. 1, pp. 421, 477, 503; vol. 2, p. 69).

84. Knuttel (1908-1916, vol. 2, p. 139; vol. 3, pp. 182, 241, 301).

85. «Op het gravamen van de sieckte der manslaghtigheit ende de censure te doen over de ledematen, die hier tegens tot remedie gebruicken de messen van de dootslaegers, is geoordeelt, dattet een duivels bedrogh is, ende grouwelicke superstitie» Knuttel (1908-1916, vol. 3, p. 539).

86. On gallows lore in Germany: Evans (1996, pp. 86-98).

87. «Bovenal in de tweegeveghten of duellen, uit andere gewesten tot de onse over gescheept, en is soo een verderffelicken schijn, dat die in onse provincien seer gewoon en voor een daet van eere beginnen gerekent te worden» Knuttel (1908-1916, vol. 3, pp. 501-503 (quote on 501-502)).

88. Knuttel (1908-1916, vol. 4, pp. 84, 149, 193).

89. Knuttel (1908-1916, vol. 5, pp. 249, 291-292, 326-327, 490, 532, 571).

90. Karonen (1998, pp. 151-159); several contributions to Rudolph, Schnabel-Schüle, eds. (2003).

91. Muchembled (1989, pp. 19-20).

92. See esp. chapter two of Frijhoff (2002). Also: Frijhoff, Spies (1999, p. 359); Spaans (2002, p. 163).

93. This argument is discussed in Spierenburg (1991, pp. 26-31).

\section{ABSTRACTS}

This article examines the attitudes of Protestant moralists and Reformed synods toward interpersonal violence in the Dutch Republic from the 1580s to the early eighteenth century. Protestants saw violence as an integral part of a sinful life style and argued that every quarrel which might lead to homicide fell under the sixth commandment. While disciplining the sometimes violent - first generation of members and ministers, the Reformed Church condemned the traditional procedure of reconciliation after a homicide, despite their preference for reconciliation in almost every other conflict. With this, the church contributed to the full criminalization of homicide. The moralists also condemned dueling and the honor code which underlay this custom. By the middle of the seventeenth century, when criminal trials for homicide had become the norm, the synods concentrated their efforts on combating the duel.

Cet article examine les attitudes des moralistes protestants et des synodes réformés à l'égard de la violence interpersonnelle dans la République des Pays-Bas des années 1580 au début du XVIII ${ }^{\text {e }}$ 
siècle. Pour les Protestants, la violence relevait d'un style de vie peccamineux et ils arguaient que toute querelle pouvant conduire à un homicide relevait du $6^{\mathrm{e}}$ Commandement. Tout en disciplinant la première génération - parfois violente - des fidèles et des pasteurs, l'Église Réformée condamnait la procédure de réconciliation traditionnelle en matière d'homicide, alors même quand celle-ci était préférée pour la plupart des autres conflits. Par là, l'Église contribua à la criminalisation complète de l'homicide. Les moralistes condamnaient également le duel et le code d'honneur qui l'inspirait. Vers le milieu du XVII ${ }^{e}$ siècle, les procès pour homicide étant devenus la norme, les synodes concentrèrent leurs efforts contre les duels.

\section{AUTHOR}

\section{PIETER SPIERENBURG}

Departments of history and criminology, Erasmus Universiteit, Postbus 1738, 3000 DR, Rotterdam - Pays-Bas, spierenburg@fhk.eur.nl

Pieter Spierenburg is a professor of historical criminology at Erasmus University, Rotterdam, the Netherlands. His current interests are in long-term trends in the history of violence and its sociocultural context; the application of historical knowledge of violence to the analysis of contemporary problems; and a comparison of violence in European and American societies. He is the author of: Written in Blood: Fatal Attraction in Enlightenment Amsterdam, Columbus, Ohio State University Press, 2004. He has also edited Social Control in Europe, Volume I, 1500-1800 (with Herman Roodenburg), Columbus, Ohio State University Press; and Social Control in Europe, Volume II, 1800-2000 (with Clive Emsley and Eric Johnson), Columbus, Ohio State University Press, 2004. 